\title{
THE EFFECT OF SULPHATE ON LENGTH CHANGE OF CONCRETE
}

\section{S. OYMAEL ${ }^{*}$}

\author{
Mustafa Kemal University \\ Department of Civil Engineering \\ 31040 Antakya, Hatay, Turkey
}

\begin{abstract}
Sulphates usually affect calcium aluminates in cements. Sulphate ions might have negative effects on cement hydration and it would be a reason of decrease in cement strength. In this study, the effects of $\mathrm{Na}_{2} \mathrm{SO}_{4}$ solution on the concretes made from OPC with oil shale ash (OSA) addition (0, 15 and $30 \%)$ were investigated. Concretes with 15\% OSA gave the lowest value of Length Change Factor (LCF). Addition of an optimum amount of superplasticizer increases positive properties of the concrete with $15 \%$ OSA addition, binds free $\mathrm{Ca}(\mathrm{OH})_{2}$ in $\mathrm{OPC}$, makes its composition more effective, prevents massive alkali-aggregates reactions showing that this addition rate is proper.
\end{abstract}

\section{Introduction}

In general, sulphate solutions affect cement mortars more aggressive than lime solutions. This indicates that cement mortars behave like a semipermeable material [1-3].

Sulphate affects generally calcium aluminates in cement. However, $\mathrm{SO}_{4}{ }^{-2}$ ions affect less than sulphate. Sulphate affects concentrate more on calcium aluminates. It is reported that cements containing more $\mathrm{C}_{3} \mathrm{~A}$ are more durable to sulphate attacks [4-7].

The solubility of calcium sulphate $\left(\mathrm{CaSO}_{4}\right)$ or gypsum is used as the standard for comparing solubility of salts that are more soluble than gypsum. Table 1 gives the data on different salts and their solubility. Pro-corrosion risk might occur in cement affected by soluble salts. Sodium $\left(\mathrm{Na}^{+}\right)$is a positively charged component or cation of salts. Sodium problems are due to its behavior when attached to clay $\left(\mathrm{Al}_{2} \mathrm{O}_{3}\right)$ particles. Examples are sodium sulphate or Glauber's salts [8].

\footnotetext{
* Corresponding author: e-mail soymael@mku.edu.tr
} 
Table 1. Composition and solubility of some common soluble minerals [8]

\begin{tabular}{|l|l|l|}
\hline \multicolumn{1}{|c|}{ Mineral } & \multicolumn{1}{|c|}{ Compound } & \multicolumn{1}{c|}{ Solubility, mol/1 } \\
\hline Calcite & $\mathrm{CaCO}_{3}($ calcium carbonate) & 0.00014 \\
Gypsum & $\mathrm{CaSO}_{4} \cdot 2 \mathrm{H}_{2} \mathrm{O}$ (calcium sulphate) & 0.0154 \\
\multicolumn{1}{|c|}{ Magnesite } & $\mathrm{CaCl}_{2} \cdot 6 \mathrm{H}_{2} \mathrm{O}$ (calcium chloride) & 7.38 \\
Hexahydrite & $\mathrm{MgCO}_{3}($ magnesium carbonate) & 0.001 \\
Epsomite & $\mathrm{MgSO}_{4} \cdot 6 \mathrm{H}_{2} \mathrm{O}$ (magnesium sulphate) & 4.15 \\
Bischofite & $\mathrm{MgSO}_{4} \cdot 7 \mathrm{H}_{2} \mathrm{O}$ (magnesium sulphate) & 3.07 \\
Washing soda & $\mathrm{MgCl}_{2} \cdot 6 \mathrm{H}_{2} \mathrm{O}$ (magnesium chloride) & 5.84 \\
Mirabilite & $\mathrm{Na}_{2} \mathrm{CO}_{3} \cdot 10 \mathrm{H}_{2} \mathrm{O}$ (sodium carbonate) & 2.77 \\
Thenardite & $\mathrm{NaSO}_{4} \cdot 10 \mathrm{H}_{2} \mathrm{O}$ (sodium sulphate) & 1.96 \\
Halite & $\mathrm{NaSO}_{4}($ sodium sulphate) & 3.45 \\
\hline
\end{tabular}

$\mathrm{Na}_{2} \mathrm{O}+\mathrm{K}_{2} \mathrm{O}$ (alkaline) are present in the component of Portland cement, and when aggregates used in production of concrete contain reactive silica or carbonate, the reaction between alkaline and aggregate occurs. This reaction causes the concrete to crack and break by dispersing after a few months or years. ASTM standards suggest the amount of alkaline not to exeed $0.6 \%$ [9].

Tricalcium aluminate hexahydrate $\left(\mathrm{Al}_{2} \mathrm{O}_{3} \cdot 3 \mathrm{CaO} \cdot 6 \mathrm{H}_{2} \mathrm{O}\right)$ forms when cement interacts with lime. Ettringite sulphoaluminate salt $\left(\mathrm{Al}_{2} \mathrm{O}_{3} \cdot 3 \mathrm{CaO} \cdot 3 \mathrm{CaSO}_{4} \cdot 30 \mathrm{H}_{2} \mathrm{O}\right)$ forms when sulphate $\left(\mathrm{CaSO}_{4} \cdot 2 \mathrm{H}_{2} \mathrm{O}\right)$ reacts with tricalcium aluminate hexahydrate. 30 molecules of water in ettringite cause stresses resulting in both a volume increase and decrease in reactions. This situation is relevant to an excess content of $\mathrm{C}_{3} \mathrm{~A}$ and $\mathrm{CaSO}_{4} \cdot 2 \mathrm{H}_{2} \mathrm{O}$ in cement. The content of $\mathrm{C}_{3} \mathrm{~A}$ and $\mathrm{C}_{3} \mathrm{~S}$ in cement should not exceed some values to preserve durability of cement to sulphate solutions. The ASTM standards suggest $\mathrm{C}_{3} \mathrm{~A}+\mathrm{C}_{3} \mathrm{~S} \leq 58 \%$ and $\mathrm{C}_{3} \mathrm{~A} \leq 8 \%$ numbers to be maintained [10].

On the other hand, the content of dissolved sulphate in water and active and passive condition of water affect concrete strength. Generally, it is considered that harmful affects start when the amount of dissolved sulphate in 1 liter water exceeds $210 \mathrm{mg}$. In swamp waters this number is $225 \mathrm{mg}$. The reaction between $\mathrm{SO}_{4}^{-2}$ and cement does not continue for a long time compared to their reactions in flowing waters. This indicates that calm waters affect less harmful than flowing waters. For calm waters, these numbers should be increased up to $50 \%$. The numbers given above should be divided to half for $\mathrm{MgSO}_{4}$, since the negative effect of $\mathrm{MgSO}_{4}$ is two times higher than that of $\mathrm{CaSO}_{4}, \mathrm{Na}_{2} \mathrm{SO}_{4}$ and $\mathrm{K}_{2} \mathrm{SO}_{4}[10]$.

Shale ash contains round glassy grains made of dry disperse substances $3 \mu \mathrm{m}$ in size with no more than $0,5 \%$ humidity [11]. It is possible to benefit from the energy produced by burning lignite as well as its ash in a thermal power plant equipped with a fluidized-bed boiler. In Germany, oil shale has been burnt in a thermal power plant for 30 years, and 400,000 tons of cement has been produced from its ash. The biggest plant that runs on the fluidizedbed burning system was established in 1986, in Duisburg [12]. In Turkey, the 
first investigations of OSA were conducted during 1974-1979 in Cayirhan county, Beypazari, Ankara, Turkey MTA. In 1987, some studies were also conducted in the framework of a Turkish-German technical coordination project.

Studies carried out by Kikas [13], Kikas with coworkers [14] and Hanni [15] showed that the addition of about 30\% OSA into Portland cement clinker can enhance compressive strength of the ordinary Portland cement. Kikas and coworkers, studying the influence of OSA on the properties of self-stressing shale ash cement, concluded that the concrete made with burnt shale is characterized by high strength, high frost resistance, and low permeability.

In this study, length changes in concrete with OSA addition $(0,15$ and $30 \%$ ) OPC burnt at $700{ }^{\circ} \mathrm{C}$ have been investigated. Permeability, expansion or changes in length, sulphate resistance, alkali-aggregate reaction and corrosion of reinforcement of concretes have been determined.

\section{Materials and methods}

\section{Cement}

The ordinary Portland cement OPC 32.5 used was obtained from Elazig Cement Factory. Chemical and physical characteristics of cement are given in Table 2.

Table 2. Chemical composition of OPC and OSA [17, 18]

\begin{tabular}{|c|c|c|c|c|c|c|}
\hline \multicolumn{2}{|l|}{$\begin{array}{l}\text { Components and } \\
\text { characteristics }\end{array}$} & \multicolumn{2}{|c|}{$\begin{array}{c}100 \% \text { OSA } \\
\text { (Oil Shale Ash) }\end{array}$} & $\begin{array}{c}0 \% \text { OSA } \\
\text { Substituted } \\
\text { Cement } \\
\text { (OPC 32.5) }\end{array}$ & $\begin{array}{c}15 \% \text { OSA } \\
\text { Substituted } \\
\text { Cement }\end{array}$ & $\begin{array}{c}\% 30 \text { OSA } \\
\text { Substituted } \\
\text { Cement }\end{array}$ \\
\hline \multicolumn{2}{|l|}{$\mathrm{CaO}$} & \multicolumn{2}{|r|}{26.40} & 63.0 & 56.16 & 50.12 \\
\hline \multicolumn{2}{|l|}{$\mathrm{SiO}_{2}$} & 39.12 & \multirow{3}{*}{$\begin{array}{c}\text { Limits [20] } \\
\mathrm{S}+\mathrm{A}+\mathrm{F} \geq 70 \%\end{array}$} & 19.78 & 16.79 & 15.45 \\
\hline \multirow{2}{*}{\multicolumn{2}{|c|}{$\begin{array}{l}\mathrm{Al}_{2} \mathrm{O}_{3} \\
\mathrm{Fe}_{2} \mathrm{O}_{2}\end{array}$}} & 7.80 & & 5.60 & 5.44 & 4.9 \\
\hline & & 4.20 & & 3.35 & 3.05 & 3.53 \\
\hline \multicolumn{2}{|l|}{$\mathrm{MgO}$} & \multicolumn{2}{|c|}{$9.26(\operatorname{Lim} . \leq 5 \%)[20]$} & 3.0 & 4.87 & 5.37 \\
\hline \multicolumn{2}{|l|}{$\mathrm{SO}_{3}$} & $5.21(\mathrm{~L}$ & Lim. $\leq 5 \%)[20]$ & 2.59 & 3.04 & 3.39 \\
\hline \multicolumn{2}{|l|}{$\mathrm{Na}_{2} \mathrm{O}+\mathrm{K}_{2} \mathrm{O}$} & & - & 0.15 & - & - \\
\hline \multicolumn{2}{|l|}{ Loss of ignition (LOI) } & $3.82(\mathrm{~L}$ & im. $\leq \% 10)[20]$ & 1.73 & 4.36 & 6.2 \\
\hline \multicolumn{2}{|l|}{$\mathrm{Cl}^{-}$} & & - & $\leq 0.1$ & - & - \\
\hline \multicolumn{2}{|c|}{ Blaine surface area, $\mathrm{cm}^{2} / \mathrm{g}$} & 6000 (I & Lim. 3000) [20] & $3180-3500$ & 3400 & 3450 \\
\hline \multicolumn{2}{|c|}{ Specific gravity $\mathrm{g} / \mathrm{cm}^{3}$} & & 2.7 & 3.15 & 3.12 & 3.11 \\
\hline \multirow{3}{*}{$\begin{array}{l}\text { Cement activity } \\
\text { (Leim activity, days) } \\
\text { [19]. Compression } \\
\text { strength, } \mathrm{N} / \mathrm{mm}^{2}\end{array}$} & 2 & & 15.3 & - & - & - \\
\hline & \begin{tabular}{|l|}
7 \\
\end{tabular} & & $3.9(13.0)$ & - & - & - \\
\hline & 28 & & $29.5(8.1)$ & - & - & - \\
\hline \multirow{2}{*}{$\begin{array}{l}\text { Compression strength } \\
\text { (Flexural strength, } \\
\text { days), N/mm } \mathrm{mm}^{2}[20]\end{array}$} & 7 & & - & $30.6(5.7)$ & $30.9(5.9)$ & $24.5(4.5)$ \\
\hline & 28 & & $10(1.8)$ & $42.6(6.8)$ & $44.4(7.0)$ & $37.8(6.5)$ \\
\hline
\end{tabular}




\section{Oil shale ash}

Oil shale ash, by its nature, is a pozzolanic material. It contains high amounts of soluble $\mathrm{SiO}_{2}$ and $\mathrm{Al}_{2} \mathrm{O}_{3}$ [16] which would react with precipitated calcium hydroxide. Oil shale ash samples used in this study were provided from the Ankara-Beypazari-Cayirhan region. Chemical and physical properties of oil shale ash are given in Table 2. Oymael [17] burnt the oil shale at different temperatures $\left(500,600,700,800,900\right.$ and $\left.1030{ }^{\circ} \mathrm{C}\right)$ and reported that OSA, processed at $700{ }^{\circ} \mathrm{C}$ for 90 minutes gives the optimum values of compressive strength for the concrete samples.

\section{Standard sand}

The sand used in the research program was of standard Rilem Cembureau type according to TS 819 [21], and it was produced in Pinarhisar, Turkey. The standard sand (SS) contained $\mathrm{ca} 90 \% \mathrm{SiO}_{2}$.

\section{Superplasticizer}

Superplasticizer (SP), obtained from SIKA, was used as an additive in amount of $0.9 \%$ of cement weight. Sikament-FF-N naphthalene formaldehyde was the superplasticizer (SP) used, and technical information given is as follows: $\mathrm{pH}$ 9, liquid, density $1.22 \mathrm{~kg} / \mathrm{l}$, proposed amount, of cement weight $0.8-3.0 \%$.

\section{Experimental}

\section{Curing of specimens}

The samples were cured in $95 \%$ humidity at $23 \pm 2{ }^{\circ} \mathrm{C}$ in the laboratory conditions for 24 hours [22], and thereafter put into the "lime saturated water bath" for standard curing. After the samples have reached the strength $20 \mathrm{~N} / \mathrm{mm}^{2}$, they were taken from the water bath and placed into sulphate solutions $\left(5 \% \mathrm{Na}_{2} \mathrm{SO}_{4}\right)$ for 90 days. Concentration of sulphate ions in the solution was $33.8 \mathrm{mg} / \mathrm{l}$ at $\mathrm{pH}$ between 6 and 8 [23-25]. To control whether the sample has reached compressive strength $20 \mathrm{~N} / \mathrm{mm}^{2}$ or not, $40 \times 40 \times 160$-mm $(40 \times 40 \times 40-\mathrm{mm})$ samples were tested. Cube samples have been found to reach $20 \mathrm{~N} / \mathrm{mm}^{2}$ in 7 days.

The ratio of corrosive (aggressive) volume to sample volume was maintained constant and less than $1 \mathrm{~cm}^{3}$ cement in reply to $1 \mathrm{ml}$ solution. The evaporation was prevented by covering the solution baths with glass plates as described in [26]. $\mathrm{Na}_{2} \mathrm{SO}_{4}$ solution is mixed time by time to be not crystallized (Fig. 1). 


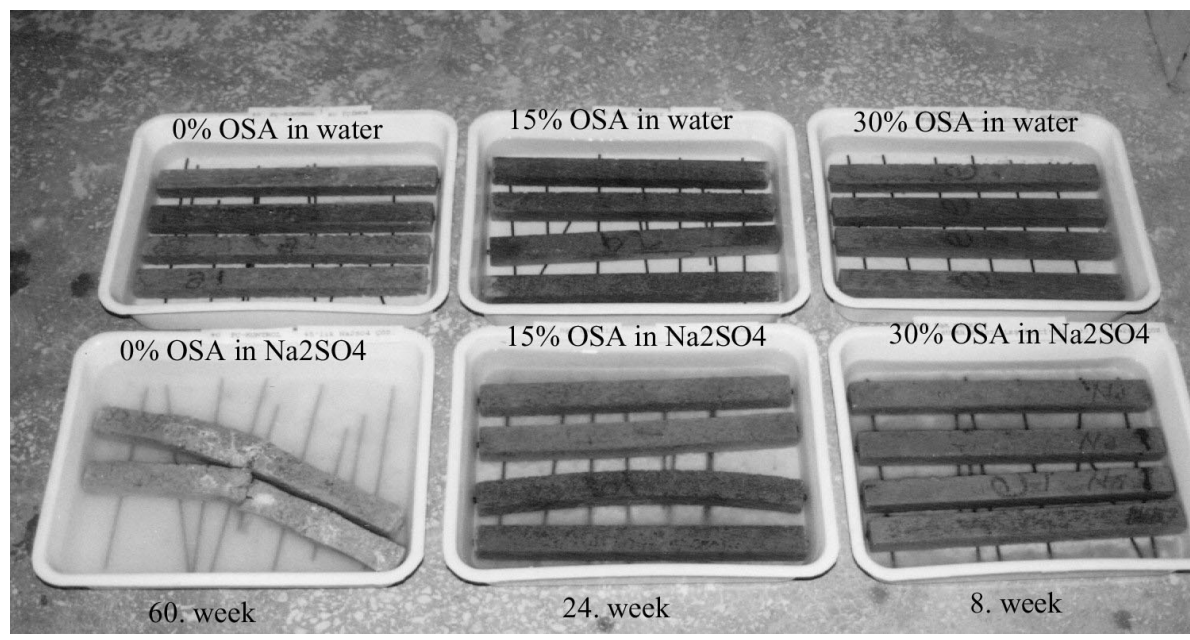

Fig. 1. Cure of mortar bars in water and sulphate colution [13].

\section{Test performed}

As stated previously, in each treatment three samples were prepared from cement substituted with 0,15 and $30 \%$ OSA additives. S/B ratio was taken constant value of 0.5 (it is 0.49 according to ACI C1012-87). The amount of optimum flow/water requirement necessary for each mix was determined using the flow table expounded in ASTM C 109, 1993, for maintaining a constant flow.

Concrete mixture design is given in Table 3 . The flow test was conducted for $70 \pm 1-\mathrm{mm}$ mortars specimen to determine water content necessary for the desired workability, the length change measurements of fresh mortar were carried out on $25 \times 25 \times 285 \mathrm{~mm}$ concrete specimen.

Table 3. Material quantities, solutions, oil shale ash (OSA), superplasticizer (SP) water/cement $(\mathrm{W} / \mathrm{C})$ ratio and slump values in production of concrete samples

\begin{tabular}{|c|c|c|c|c|c|c|c|c|}
\hline \multirow[t]{2}{*}{ No } & \multirow{2}{*}{$\begin{array}{c}\text { Substitute } \\
\text { Ratio }\end{array}$} & \multirow{2}{*}{$\begin{array}{l}\text { Water, } \\
\text { solutions }\end{array}$} & \multicolumn{3}{|c|}{ Quantity, $\mathrm{kg} / \mathrm{m}^{3}$} & \multicolumn{3}{|c|}{ Ratios, \% } \\
\hline & & & OPC 32.5 & OSA & SS & SP & W/C & Flow \\
\hline 1 & $0 \%$ & $\begin{array}{c}\text { Water }-1 \\
\mathrm{Na}_{2} \mathrm{SO}_{4}-1\end{array}$ & 330 & - & 1000 & - & 0.57 & 105 \\
\hline 2 & $\begin{array}{l}0 \% \\
\text { (SP) }\end{array}$ & $\begin{array}{c}\text { Water -2 } \\
\mathrm{Na}_{2} \mathrm{SO}_{4}-2\end{array}$ & 330 & - & 1000 & 0.9 & 0.46 & 106 \\
\hline 3 & $15 \%$ & $\begin{array}{c}\text { Water -3 } \\
\mathrm{Na}_{2} \mathrm{SO}_{4}-3\end{array}$ & 280 & 50 & 1000 & - & 0.62 & 108 \\
\hline 4 & $\begin{array}{l}15 \% \\
\text { (SP) }\end{array}$ & $\begin{array}{c}\text { Water -4 } \\
\mathrm{Na}_{2} \mathrm{SO}_{4}-4\end{array}$ & 280 & 50 & 1000 & 0.9 & 0.51 & 106 \\
\hline 5 & $30 \%$ & $\begin{array}{c}\text { Water -5 } \\
\mathrm{Na}_{2} \mathrm{SO}_{4}-5\end{array}$ & 230 & 100 & 1000 & - & 0.67 & 105 \\
\hline 6 & $\begin{array}{l}30 \% \\
\text { (SP) }\end{array}$ & $\begin{array}{c}\text { Water }-6 \\
\mathrm{Na}_{2} \mathrm{SO}_{4}-6\end{array}$ & 230 & 100 & 1000 & 0.9 & 0.55 & 107 \\
\hline
\end{tabular}


Table 4 shows compressive and flexural $(40 \times 40 \times 160 \mathrm{~mm})$ strengths of mixtures measured after 7, 28 and 180 days, plotted against ash amount in binder. One can see that compressive strength decreases with increasing ash content in the concrete mixtures, and the highest strength of mixtures containing OSA is achieved at the age of 28 days.

Table 4. Compressive and flexural $(\mathbf{4 0} \times \mathbf{4 0} \times \mathbf{1 6 0} \mathbf{~ m m})$ strengths of mixtures measured after 7, 28 and 180 days, depending on ash amount in binder

\begin{tabular}{|l|c|c|c|c|}
\hline & days & $\begin{array}{c}0 \% \text { OSA } \\
(100 \% \text { OPC })\end{array}$ & $\begin{array}{c}15 \% \\
\text { OSA }\end{array}$ & $\begin{array}{c}30 \% \\
\text { OSA }\end{array}$ \\
\hline Compressive and & 7 & $30.6(5.7) 28^{*}$ & $30.9(5.9) 22^{*}$ & $24.5(4.5) 18^{*}$ \\
flexural strength, & 28 & $42.6(6.8) 36^{*}$ & $44.4(7) 32^{*}$ & $37.8(6.5) 27 *$ \\
$\mathrm{~N} / \mathrm{mm}^{2}$ & 180 & $51(7.4)$ & $55.5(8.5)$ & $52.7(8.9)$ \\
\hline
\end{tabular}

*Measurements by Al-Hasan [27]

\section{Measurement of samples}

Samples were formed according to [28], standards and special $\varnothing 6 \mathrm{~mm}$ noncorrosive bolts were placed at the ends of samples. The distances between the bolts with the formwork were $250 \pm 2.5 \mathrm{~mm}$, the length inside the specimen was $7.5 \pm 0.5 \mathrm{~mm}$ and outside the specimen $-5 \mathrm{~mm}$.

The length of the concrete specimens was measured in \pm 0.002 error range with the device shown in Fig. 2. At the measurements, great pains were taken to calibrate dial indicator and to clean the grooves in which the specimens were put.

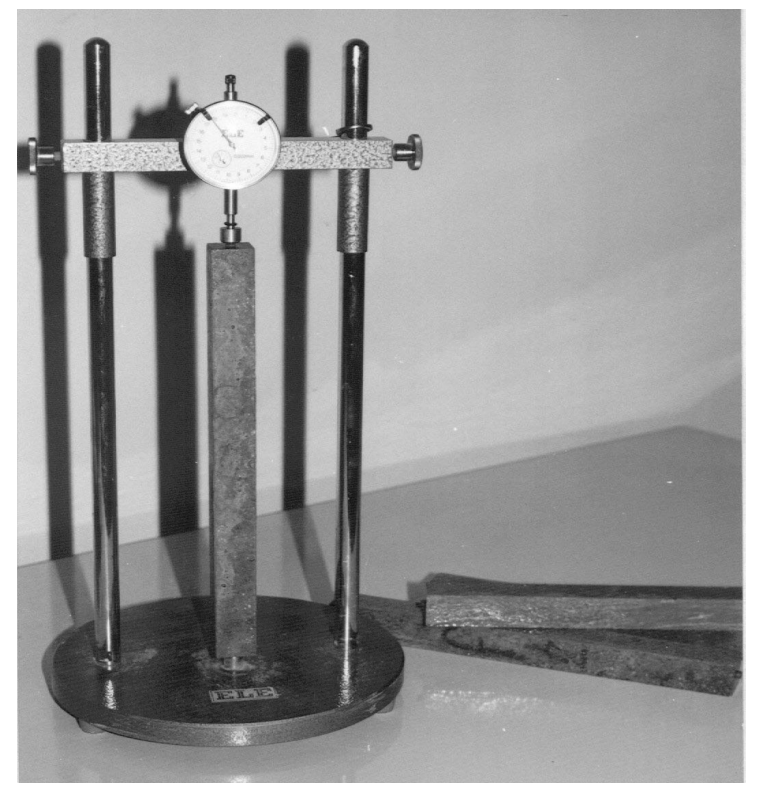

Fig. 2. Measurement of mortar bars with dial indicator. 
The samples were measured with a dial indicator within the first ten minutes, thereafter they were taken out of the solution and put back into the solution again.

Length Change Factor (LCF) in prismatic concrete bars, calculated using four-week measurements, are given in Table 5, Figures 3, 4 and 5. LCF was calculated as follows:

$$
\operatorname{LCF}(\%)=\mathrm{L}_{\mathrm{n}}-\mathrm{L}_{0} / 285 \times 100,
$$

where LCF is Length change factor, \%

$\mathrm{L}_{0}$ - length measurement value of four-week prismatic sample, $10^{-3} \mathrm{~mm}$,

$L_{n}$ - length measurement value at the end of test, $10^{-3} \mathrm{~mm}$.

Table 5. Length change factor of OSA blended concrete

\begin{tabular}{|c|c|c|c|c|c|c|c|c|c|}
\hline \multirow{2}{*}{ No } & Compound & Solution & \multicolumn{7}{|c|}{ Length Change Factor (LCF), \% } \\
& & & \multicolumn{7}{|c|}{ Week } \\
\cline { 4 - 10 } & & & 8 & 12 & 16 & 24 & 36 & 52 & 60 \\
\hline 1 & $0 \%$ OSA & water & 0.018 & 0.036 & 0.056 & 0.146 & 0.386 & 1.343 & 3.538 \\
& $(100 \%$ OPC) & & & & & & & & \\
& $\left(\right.$ Contr.) $\left(10^{-3}\right)$ & $\mathrm{Na}_{2} \mathrm{SO}_{4}$ & 0.037 & 0.199 & 0.993 & 1.50 & 2.012 & 2.118 & 4.33 \\
2 & $15 \%$ OSA $\left(10^{-3}\right)$ & water & 0.003 & 0.072 & 0.136 & 0.147 & 0.512 & 1.224 & 1.228 \\
& & $\mathrm{Na}_{2} \mathrm{SO}_{4}$ & 0.336 & 0.375 & 0.445 & 0.482 & 0.713 & 0.945 & 1.863 \\
3 & $30 \%$ OSA $\left(10^{-3}\right)$ & water & 0.025 & 0.059 & 0.072 & 0.032 & 0.438 & 1.308 & 1.471 \\
& & $\mathrm{Na}_{2} \mathrm{SO}_{4}$ & 0.021 & 0.074 & 0.188 & 0.200 & 0.458 & 1.513 & 2.134 \\
4 & $30 \%$ OSA $(\mathrm{SP})$ & water & 0.015 & 0.024 & 0.112 & 0.151 & 0.467 & 0.75 & 1.047 \\
& $\left(10^{-3}\right)$ & $\mathrm{Na}_{2} \mathrm{SO}_{4}$ & 0.003 & 0.050 & 0.092 & 0.134 & 0.375 & 1.303 & 1.307 \\
\hline
\end{tabular}

Note: Values for the first measurements of samples during the 4th week are not included in this table.

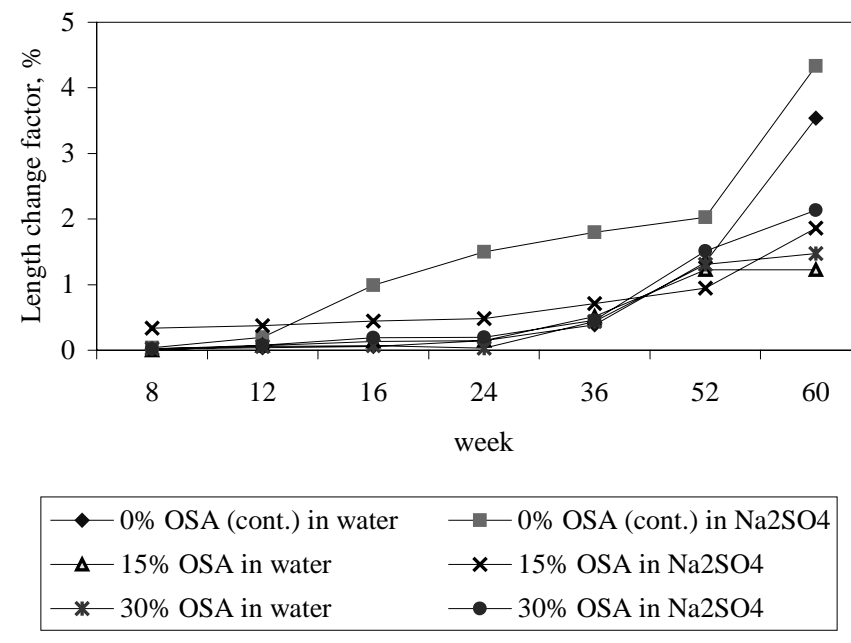

Fig. 3. Expansion of $0 \%, 15 \%, 30 \%$ OSA added concretes in $\mathrm{Na}_{2} \mathrm{SO}_{4}$ mixtures and water. 


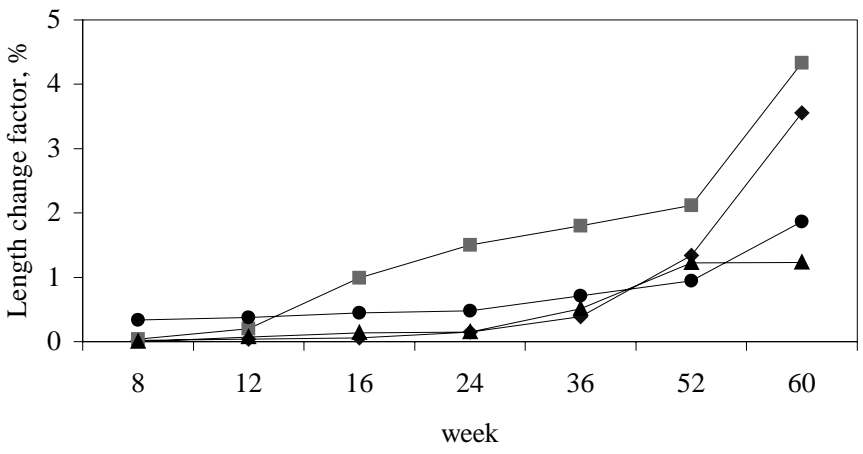

$\checkmark 0 \%$ OSA (Cont.) Water —- $0 \%$ OSA (Na2SO4)

$\triangle 15 \%$ OSA (Water) $\longrightarrow 15 \%$ OSA (Na2SO4)

Fig. 4. Expansion of $0 \%, 15 \%$ OSA added concretes in $\mathrm{Na}_{2} \mathrm{SO}_{4}$ mixtures and water.

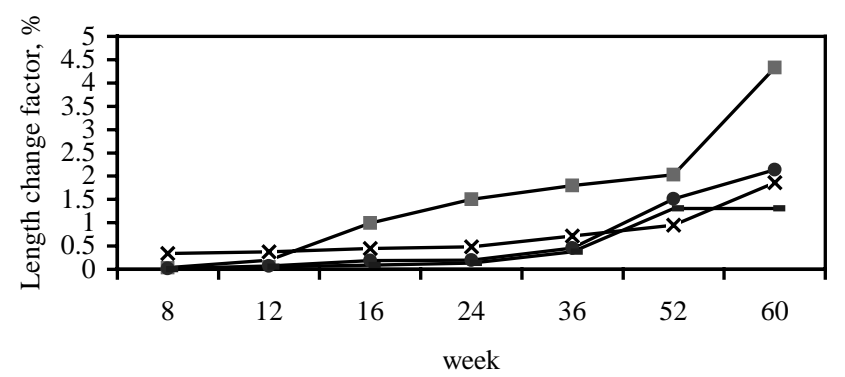

$\longrightarrow-0 \%$ OSA (cont.) in Na2SO4 $-x-15 \%$ OSA in Na2SO4
$\longrightarrow-30 \%$ OSA in Na2SO4 $-30 \%$ OSA (SP) in Na2SO4

Fig. 5. Expansion of $0 \%, 15, \%, 30 \%$ OSA added concretes in $\mathrm{Na}_{2} \mathrm{SO}_{4}$ mixtures.

\section{Conclusions}

This study was carried out in two parts. First, measurement of the compressive strength of $40 \times 40 \times 160$-mm samples ( 3 samples from each mixed total of 54 samples), second, measurement of the length change of $25 \times 25 \times 285$-mm concrete specimens (4 samples from each mixed total 72 samples). The length of concrete samples has been measured following the basic rules after 1, 2, 3, 4, 8, 13, 15, 24, 36, 48, 52 and 60 weeks according to ASTM C1012-87. LCF values of concrete in water and $\mathrm{Na}_{2} \mathrm{SO}_{4}$ solution are given in Table 5 and Figures 3, 4 and 5. 
All samples in the solution have demonstrated the characteristics like length extension and shrinkage to be unstable during the initial weeks. However, 4 weeks later the value of length extension for concrete was already stable. Dimensional variability during the initial weeks can be attributed to $\mathrm{C}-\mathrm{S}-\mathrm{H}$ (calcium silicate hydrate), as gels are filling the pores in concrete during hydration.

LCF values of all 0,15 and 30\% OSA-added concrete have been measured within sixty weeks. The lowest value of LCF has been achieved for $15 \%$ OSA-added concrete. Deformations of concrete bars of OPC control sample bars according to age are shown in Fig. 4.

Adding SP to concrete exerted positive effect on concrete samples. $30 \%$ OSA-blended cement with SP addition demonstrates the same LCF value as $15 \%$ OSA-added sample without SP.

The value of length extension for 14 days of samples with OSA addition much below the limits $0.020 \%$, is proper for fly ashes according to ASTM C 618 [29]. According to ASTM C 33 and ASTM C227, 10\% expansion limit at the 52nd week is anticipated on the concrete mortar bars. This limit is not passed over by $15 \%$ OSA-added concrete sample in water. The addition of $15 \%$ OSA into the OPC effectively prevents free $\mathrm{Ca}(\mathrm{OH})_{2}$ and the reactions between alkali aggregates. Oymael [17] has proved the suitability of $15 \%$ oil shale ash as an admixture in cement and concrete.

Compression strength values given in the present study to determine length change factor values, are 10-30\% higher than those measured by Al-Hassan [27] (Table 4). Differences in the values may be caused by differences in sample dimensions because $40 \times 40 \times 40-\mathrm{mm}$ samples used in the present study are smaller than Al-Hassan's 70 $\pm 1-\mathrm{mm}$ samples. The shorter the specimen, the higher the value of compressive strength.

\section{Acknowledgements}

The author would like to thank Prof. Dr. Asım Yeğinobali, retired faculty member of Middle East Technical University (METU) and Assoc. Prof. Dr. Yalçın Tepe current Research and Development Director of the Turkish Cement Manufacturers' Association.

\section{REFERENCES}

1. Ushiyama, G. Diffusion of various ions in hardened Portland cement paste. Proc. VI. ICCC. Sec. II, 1975.

2. Podvalnyi, A. M. Phenomenological aspect of concrete durability theory// Materials and Structures. 1976. Vol. 9, No. 51. P. 151-162.

3. TMMOB Turkish Chamber of Civil Engineers Istanbul Branch, Durability of concrete, proceedings, 5. National Congress on Concrete, Harbiye-Istanbul, 1-3 October 2003 [in Turkish]. 
4. Schramli, W. An attempt to assess beneficial and detrimental effects of alüminate in the cement on concrete performance. Part. II. // World Cement Technology. 1979. No. 3, P. 75-80.

5. Durmuş, A. Aluminous cements in reinforced concrete // J. Turkish Eng. News. Turkish Chamber of Civil Engineers. 1981. No. 297. P. 23-24 [in Turkish].

6. Dreux, G. Nouveau Guide du Béton, Ed. Eyrolles, Paris, 1986.

7. Akman, M.S. Concrete Technology of Marine Structures, ITU Library, No. 1481, Istanbul, 1992. P. 132-206 [in Turkish].

8. Seelig, B. D. Salinity and sodicity in North Dakota soils. 1984. http://www.ext.nodak.edu/extpubs/plantsci/soilfert/eb57-1.htm (27.5.2002)

9. Erdoğan, T. Concrete. - METU Pres Publishing Company, Turkey, 2003. P. 741 [in Turkish].

10. Neville, A. M. Properties of Concrete. - London, Pitman Publishing Ltd., 1983. P. 433-528.

11. The European Cement Association, cement manufacturing by using industrial wastes. - Ankara Cement Manufacturers' Association, Ankara, 1985 [in Turkish].

12. Mine Survey Search General Directorate, oil shale and oil shale ore in Turkey, service special report number: 9202. - Ankara, Turkey, 1989 [in Turkish].

13. Kikas, V. Application of oil shale ash in the building materials industry. - UN Symposium of Oil Shale Resources, Tallinn, 1968.

14. Kikas, V., Rass, J., Hralovich, J. Influence of ash content of Kukeriste oil shale on the properties of self-stressing shale ash cement// Proceedings of Tallinn Polytechnic Institute. 1986. No. 618. P. 9-17.

15. Hanni, R. Energy and valuable material by-product from firing Estonian oil shale // Waste Management. 1996. Vol. 16, No. 1. P. 97-99.

16. Al-Dulaijan, S. U., Maslehuddin, M., Al-Zahrani, M. M., Sharif, A. M., Shameem, M., Ibrahim, M. Sulfate resistance of plain and blended cements exposed to varying concentrations of sodium sulfate // Cement and Concrete Composites. 2003. Vol. 25, No. 4-5. P. 429-437.

17. Oymael, $S$. The suitability of oil shale ash as an admixture in cement and concrete. - PhD Dissertation. Firat University, Elazig, 1995. 163 pp. [in Turkish].

18. Oymael, S., Durmuş, A. Effects of sulphates on elastic modulus of concrete samples made from blends of cements with oil shale ash // Oil Shale. 2006. Vol. 23, No. 2. P. 125-134.

19. ASTM C 109. Test method for compressive strength of hydraulic cement mortars. 1993 Annual Book of ASTM Standards. Vol. 04.01.

20. Turkish Standards, TS 25 - Trass. Turkish Standards Institution, Ankara, 1975.

21. Turkish Standards, TS 819 - Rilem Cembureau Sand. Turkish Standards Institution, Ankara, 1989.

22. ASTM C 311-04. Sampling and Testing Fly Ash for Natural Pozzolans for Use in Portland-Cement Concrete.

23. ASTM C 1012-87, Standard Test Method for Length Change of HydroulicCement Mortars Exposed to Sulfate Solution.

24. ACI 201. 2R-77, Guide to Durable Concrete, Chapter 3, Abrasion. ACI Manual of Concrete Practice, Part I. - Detroit, 1986

25. Tuthill, L. H. Resistance to Chemical Attack. - ASTM Sp. Tech. Publicn. No. 169 B, 1978. P. 369-387. 
26. Madej, J. Corrosion resistance of normal and silica fume-modified mortars made from different types of cement. Istanbul Conference, 1992. P. 1189-1196.

27. Al-Hasan, M. Behavior of concrete made using oil shale ash and cement mixtures // Oil Shale. 2006. Vol. 23, No. 2. P. 135-143.

28. ASTM C 490-93a. Standard Practice for Use of Apparatus for the Determination of Length Change of Hardened Cement Paste, Mortar and Concrete, 1993.

29. Hooton, $R$. D. Influence of silica fume replacement of cement on physical properties and resistance to sulfate attack, Freezing and Thawing, and AlkaliSilica Reactivity, ACI Materials Journal (Technical Paper). 1993. Vol. 90, No. 2. P. 143-151.

Presented by M. Kök

Received June 12, 2006 